\title{
Perancangan Pembangkit Listrik Tenaga Mikro Hidro Kapasitas Daya 50 KW
}

\author{
Dian Fatahudin ${ }^{1}$, Itmi Hidayat Kurniawan ${ }^{2}$ \\ Program Studi S1 Teknik Elektro, Universitas Muhammadiyah Purwokerto \\ Fakultas Teknik dan Sains, Universitas Muhammadiyah Purwokerto
}

\section{Informasi Makalah}

Dikirim, 16 Agustus2019

Direvisi, 27 November 2019

Diterima, 14 Januari 2020

\section{Kata Kunci:}

PLTMH, Etap, Turbin

Crossflow, Solidworks

\begin{abstract}
INTISARI
Pembangkit Listrik Tenaga Mikro Hidro (PLTMH) suatu pembangkit listrik berskala kecil yang menggunakan tenaga air sebagai penggeraknya, dengan cara memanfaatkan tinggi terjunnya air (head satuan meter) dan jumlah debit airnya $\left(\mathrm{m}^{3} / \mathrm{s}\right)$. Prinsip PLTMH dari perubahan tenaga potensial air menjadi tenaga listrik dengan Tenaga potensial adalah tenaga air karena berada pada ketinggian, Tenaga kinetik adalah tenaga air karena mempunyai kecepatan, Tenaga mekanik adalah tenaga kecepatan air yang terus memutar runner atau sudu-sudu turbin. Tujuannya Perancang pembangkit listrik tenaga mikro hidro dengan tinggi jatuh air 5 meter menggunakan turbin crossflow dengan daya $50 \mathrm{~kW}$, desain komponen-komponen mekanik menggunakan software Solidworks. Dan mensimulasikan kelistrikannya mengunakan software etap 12.6.0. Hasil perancangan mekanik generator yang digunakan kapasitas daya $55 \mathrm{~kW}$ mengacu pada data teknikal dari IEC frame size tipe Y2 250M 2 dan perancanga turbin crossflow dengan tinggi jatuh air 5 meter debit $1,3 \mathrm{~m}^{3} / \mathrm{s}$ dan efisiensi turbin $82 \%$ daya yang dihasilkan hanya $52,2 \mathrm{~kW}$. Perancangan kelistrikan dari sisi Main Distribution Panel (MDP) yang digunakan proteksi MMCB NSX160F 36kA 3P 160 A, dan current transformer sekala 1:100, kabel pada transmisi yang digunakan a sudrado tipe AAAC/S 300 $\mathrm{mm}^{2}$ sepanjang $1 \mathrm{~km}$, sisi Sub Distribution Panel (SDP) proteksi yang digunakan MCCB tipe TM80D 115 A, kabel yang digunakan kabel sudrado tipe NFA2X AAC/S 2x16 sepanjang $10 \mathrm{~m}$. Dan perancangan pempembangkit listrik mikro hidro (PLTMH) dengan daya $50 \mathrm{~kW}$ mebutukan estimasi anggaran biaya produksi sebesar Rp 499,058,000. Perhitungan dan nilai BEP 2 tahun +6 bulan +3 hari atau dapat mencapai titik impas sebelum umur ekonomis pembangkit 10 tahun.
\end{abstract}

Keyword:

MHPP, Etap, Crossflow Turbine, Solidworks

\begin{abstract}
Micro Hydro Power Plant (PLTMH) a small-scale power plant that uses hydropower as its driving force, by utilizing the height of waterfall (head unit meter) and the amount of water discharge ( $\mathrm{m} 3 / \mathrm{s})$. The principle of PLTMH from the change of potential water power into electric power with potential power is hydropower because it is at an altitude, kinetic power is hydropower because it has speed, mechanical power is the speed of water that continues to turn the runner or blade of the turbine. The goal is to design a micro hydro power plant with a 5 meter high water fall using a crossflow turbine with a power of $50 \mathrm{~kW}$, the design of mechanical components using Solidworks software. And simulate the electricity using etap 12.6.0 software. The results of the mechanical design of the generator used $55 \mathrm{~kW}$ power capacity refers to technical data from the IEC frame size type Y2 250M 2 and crossflow turbine design with 5 meters high water fall discharge $1.3 \mathrm{~m} 3 / \mathrm{s}$ and turbine efficiency $82 \%$ of the power generated is only $52,2 \mathrm{~kW}$. Electrical design from the Main Distribution Panel (MDP) used by MMCB NSX160F 3P 160 A protection, and 1: 100 scale current transformers, cables on the transmission used a sudrado type AAAC/S $300 \mathrm{~mm} 2$ along $1 \mathrm{~km}$, the Sub
\end{abstract}


Distribution Panel (1 km) SDP) protection used MCCB type TM80D $115 \mathrm{~A}$, the cable used NFA2X AAC / S type 2x16 type sudrado cable along $10 \mathrm{~m}$. And the design of a micro hydro power plant (PLTMH) with $50 \mathrm{~kW}$ power requires an estimated production cost budget of Rp. 499,058,000. Calculation and BEP value of 2 year +6 month +3 day or can break even before the economic life of the plant is 10 years

\section{Korespondensi Penulis:}

Dian fatahudin

Program Studi Teknik Elektro

Fakultas Teknik dan Sains Universitas Muhammadiyah Purwokerto

JL. Raya Dukuhwaluh, Purwokerto, 53182

Email: fatahudindian@gmail.com

\section{PENDAHULUAN}

Pembangkit Listrik Tenaga Mikro hidro (PLTMH), biasa disebut mikro hidro, adalah suatu pembangkit listrik berskala kecil yang menggunakan tenaga air sebagai penggeraknya, misalnya saluran irigasi, sungai atau air terjun alam, dengan cara memanfaatkan tinggi terjunnya (head, dalam meter) dan jumlah debit airnya $\mathrm{m}^{3} /$ detik.

Bentuk pembangkit listrik tenaga mikro hidro bervariasi, tetapi prinsip kerjanya sama, yaitu perubahan tenaga potensial air menjadi tenaga elektrik (listrik). Perubahan yang terjadi tidak secara langsung, tetapi berturut-turut melalui tahapan sebagai berikut :

1. Tenaga potensial diubah menjadi tenaga kinetik

2. Tenaga kinetik diubah menjadi tenaga mekanik

3. Tenaga mekanik diubah menjadi tenaga listrik

\section{METODE PENELITIAN}

Pada bab ini dijelaskan mengenai alur dari penelitian perancangan pembangkit listrik tenaga mikro hidro dengan kapasitas daya $50 \mathrm{~kW}$ dan tinggi jatuh 5 meter dengan debit air yang sudah ditentukan yaitu $1,3 \mathrm{~m}^{3} / \mathrm{s}$. Perancangan pembangkit listrik tenaga mikro hidro ini dimulai dengan mengumpulkan data-data spesifikasi tinggi jatuh dan debit air, kemudian menghitung prakiraan daya yang akan dihasilkan oleh turbin berdasarkan spesifikasi kedua parameter tersebut. Setelah mengetahui prakiraan daya yang dihasilkan dapat diketahui besarnya kecepatan putaran turbin saat beroperasi. 


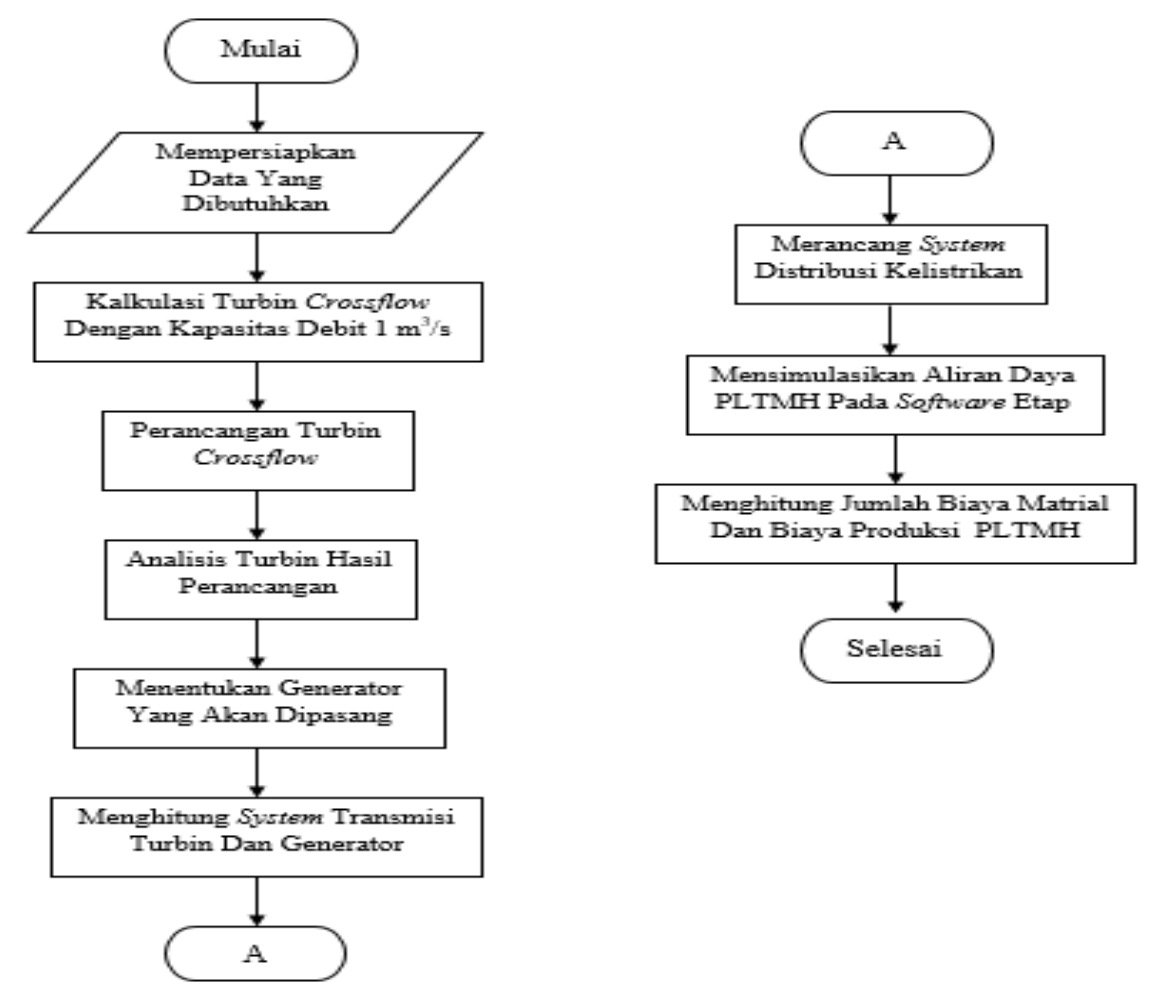

Gambar 1. Alur Penelitian Perancangan Pembangkit Listrik Tenaga Mikro Hidro

\section{HASIL DAN PEMBAHASAN}

Pada pemilihan turbin crossflow pada penelitian ini didasarkan pada karakter pengoperasian yang luas dan bisa digunakan di hampir seluruh tipe head. Turbin crossflow juga merupakan satu-satunya turbin impuls yang dapat digunakan pada head rendah. Selain itu efisiensi dari turbin crossflow yang tinggi juga menjadi salah satu dasar dipilihnya turbin ini di dalam penelitian ini. Efisiensi turbin crossflow sendiri sangat dipengaruhi oleh desain dari komponen-komponen penyusunnya dimana komponen-komponen tersebut meliputi diameter dan panjang runner, jumlah dan jarak antar blade, lebar dari nosel, serta sudut dari inlet dan outlet dari turbin. Sehingga diperlukan komponen yang mampu memiliki tingkat efisiensi tinggi.

Berdasarkan dari batasan masalah yang telah dijelaskan sebelumnya bahwa yang akan digunakan disini merupakan head optimis yaitu sebesar 5 meter. Debit air yang digunakan disini merupakan debit ratarata air sungai yaitu sebesar $1,3 \mathrm{~m}^{3} / \mathrm{s}$. 
Table 1 Spesifikasi Komponen System Mekanik

\begin{tabular}{ll}
\hline Komponen & Spesifikasi \\
\hline Jenis Turbin & Cross Flow \\
\hline Panjang Runner & $1,22 \mathrm{~m}$ \\
\hline Tinggi Jatuh & $5 \mathrm{~m}$ \\
\hline Debit Aliran & $1,3 \mathrm{~m}^{3} / \mathrm{s}$ \\
\hline Efisiensi & $82 \%$ \\
\hline Kecepatan Turbin & $262,61 \mathrm{rpm}$ \\
\hline Sudu & 21 buah \\
\hline Daya Turbin & $52,2 \mathrm{~kW}$ \\
\hline Material Turbin & Shaft Runner Mild Steel St 37 \\
\cline { 2 - 2 } & Sudu Runner \& Piringan Mild \\
& Steel St 37 \\
\cline { 2 - 2 } Housing Mild Steel St 37 \\
SKaring $: 22218$ EK + H318 \\
\hline
\end{tabular}

Generator yang digunakan pada penelitian ini mengacu pada data teknikal dari IEC frame size generator dimana untuk daya sebesar $55 \mathrm{~kW}$ dengan 4 kutub harus menggunakan tipe Y2 250M 2 dengan spesifikasi sudah terlampir seperti pada tabel IEC frame size. Pemilihan generator ini dimaksudkan agar memudahkan perancangan PLTMH $50 \mathrm{~kW}$ sendiri karena dengan menggunakan generator yang tercantum pada IEC frame size maka akan memudahkan dalam proses maintenance atau penggantian spare part, lain halnya jika menggunakan generator dengan desain yang menyesuaikan dengan kecepatan turbin yang memiliki tingkat kompleksitas yang lebih tinggi dan cukup menyulitkan bagi pengguna nantinya dalam melakukan perawatan dan penggantian spare part.

Untuk spesifikasi dari generator dengan berbagai macam output dapat dilihat pada tabel 2.

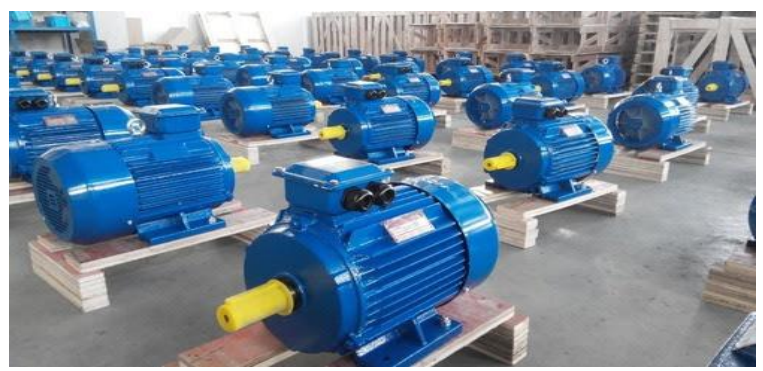

Gambar 2. Generator Singkron Tipe Y2 250M2 55 kW 
Tabel 2. Spesifikasi Generator Singkron Tipe Y2 250M2 $55 \mathrm{~kW}$

\begin{tabular}{ll}
\hline Nama & Spesifikasi \\
\hline IEC Frame Size & Y2-250M-4 \\
\hline Merk & STC 3 Phase Synchronous Generator \\
\hline Model & STC-30 \\
\hline Daya & $55 \mathrm{~kW}$ \\
\hline Tegangan & $380 \mathrm{Volt}$ \\
\hline Fase & 3 Fase terhubung Y \\
\hline Kecepatan Putaran & 1500 rpm \\
\hline Frekuensi & $50 \mathrm{~Hz}$ \\
\hline Kutub & 4 \\
\hline Horse Power & $75 \mathrm{HP}$ \\
\hline Arus & $102.9 \mathrm{Amps}$ \\
\hline Efficiency & $96 \%$ \\
\hline Cos $\varphi$ & 0,86 \\
\hline Exciter & Built In Brushless Exciter \\
Ballast Load & Heater $10 \mathrm{~kW}$ \\
Harga & Rp 11.305.000 \\
\hline
\end{tabular}

Untuk mengetahui kabel yang akan digunakan dan menentukan yang sudah banyak dipasaran. Diketahui : Daya keluaran generator total $52,2 \mathrm{~kW}$, tegangan pada generator $380 \mathrm{~V}$. Untuk mengetahui pada ujung pembebanan $\mathrm{V}=$ tegangan pada sisi pembankitan $=380 \mathrm{~V}-\mathrm{Vr}=$ besar drop voltage penyaluran $=19,7$ $\mathrm{V}=360,3 \mathrm{~V}$ dan presentase rugi tegangan $(19,7 \mathrm{~V}: 380 \mathrm{~V}) \times 10 \%=5 \%$ artinya masih dalam standart PLN. Dengan jenis kabel sesuai SPLN 64: 1985 yang memiliki tipe AAAC ukuran $300 \mathrm{~mm}^{2}$, dan untuk mengurangi tejadinya drop voltage pada system distribusi daya $52,2 \mathrm{~kW}$ digunakan kabel dengan merk Sutrado Kabel.

Tabel 3. Spesifikasi Merk Kabel Sudrado Tipe AAAC/S XLPE

\begin{tabular}{|c|c|c|c|c|c|c|c|c|}
\hline \multicolumn{9}{|c|}{ Tipe AAAC/S } \\
\hline Angka & Ukuran & Jumlah & Diameter & Berat & Daya & Resita & Kuat & Panjang \\
\hline Ukuran & Sebenarnya & Dan & Keseluruhan & Bersih & Tarik & nsi & Hantar & \\
\hline & & $\begin{array}{c}\text { Diametr } \\
\text { Kawat }\end{array}$ & & & & & $\begin{array}{c}\text { Arus } \\
\text { (Kha) }\end{array}$ & \\
\hline $\mathrm{mm}^{2}$ & $\mathrm{~mm}^{2}$ & $\mathrm{pcs} / \mathrm{mm}$ & $\mathrm{Mm}$ & $\mathrm{kg} / \mathrm{km}$ & $\mathrm{kg}$ & $\mathrm{Ohm} / \mathrm{k}$ & A & $\mathrm{m}$ \\
\hline & & & & & & $\mathrm{m}$ & & \\
\hline 300 & 299,40 & $61 / 2,50$ & 30,10 & 1,052 & 8,530 & 0.111 & $115-670$ & 1,000 \\
\hline
\end{tabular}

Dengan mengetahui arus beban penuh dari generator tersebut, pada MCCB disetting arus maksimum saat generator berbeban. dan arus ini biasa disebut arus starting beban yang nilainya bisa mencapai 1,5 kali dari arus nominal generator saat beban penuh. Sehingga MCCB dipilih yang memiliki rating 160 A, karena 1,5 kali dari $92 \mathrm{~A}$ adalah 138.4 A.

Maka MCCB yang digunakan dalam penelitian ini produksi dari Schneider tipe NSX160F 36kA 3P 87.5-125A TM125D LV430631. MyugasCCB ini merupakan MCCB umum sangat mudah ditemukan tokotoko elektronik maupun jual beli online, hal ini dimaksudkan agar memudahkan penggunan untuk mengganti spare part jika mengalami kerusakan.

Untuk mengetahui kabel yang akan digunakan dan menentukan yang sudah banyak dipasaran. Diketahui : Daya keluaran beban lump dan motor $75 \%$ total $39,1 \mathrm{~kW}$, tegangan pada generator $380 \mathrm{~V}$, dan frekuensi keluaran generator 0.86. Dengan jenis kabel sesuai SPLN 64: 1985 yang memiliki tipe AAC ukuran $12 \mathrm{~mm}^{2}$, dengan merk Sutrado Kabel.

Halaman Web JRRE : http://jurnalnasional.ump.ac.id/index.php/JRRE 
Tabel 4. Spesifikasi merk kabel sudrado tipe NFA2X AAC/S

\begin{tabular}{|c|c|c|c|c|c|c|}
\hline \multicolumn{7}{|c|}{ Tipe NFA2X AAC/S } \\
\hline $\begin{array}{c}\text { Ukuran } \\
\text { Kabel }\end{array}$ & Ketebalan Isolasi & $\begin{array}{l}\text { Berat } \\
\text { Bersih }\end{array}$ & $\begin{array}{c}\text { Resistan } \mathrm{Si} \\
\text { Konduktor } 20^{0} \mathrm{c}\end{array}$ & $\begin{array}{c}\text { Kuat } \\
\text { Hantar } \\
\text { Arus }\end{array}$ & $\begin{array}{l}\text { Kuat } \\
\text { Daya } \\
\text { Tarik }\end{array}$ & $\begin{array}{l}\text { Standar } \\
\text { Panjang }\end{array}$ \\
\hline $\mathrm{mm}^{2}$ & $\mathrm{~mm}$ & $\mathrm{~kg} / \mathrm{km}$ & $\mathrm{Ohm} / \mathrm{km}$ & A & $\mathrm{kg}$ & $\mathrm{m}$ \\
\hline $2 \times 16 \mathrm{rm}$ & 1,2 & 138 & 0,019 & 72 & 515 & 10 \\
\hline
\end{tabular}

Sebagai Pengamanan dari beban sendiri menggunakan sebuah proteksi MCCB, dimana memiliki 2 fungsi yang berbeda-beda untuk mengamankan generator jika terjadi bebah lebih dari $75 \%$. MCCB pertama, digunakan untuk mengamankan generator dari arus lebih saat dibebani secara penuh secara terus-menerus. Dengan mengetahui rating daya generator sebesar $39,1 \mathrm{~kW}$ karena memperhitungkan power factor sebesar 0,86 .

Pada Gambar 3 dengan kapasitas beban $75 \%$ dapat dilihat aliran daya yang di distribusikan oleh generator tegangan $380 \mathrm{v}$, daya $44 \mathrm{~kW}$, arus 67,2 A, dan power faktor 90,4\%. Terdistribusi 100\% kebeban motor 19,5 kW tegangan $380 \mathrm{~V}$, daya $25 \mathrm{~kW}$, arus 37,6 A, power aktor 88,8\%, beaban lump 19,5 kVA tegangan $380 \mathrm{~V}$, daya $16 \mathrm{kVA}$, arus 29,6 A, power faktor $85 \%$. jadi simulasi etap sistem kelistrikan pltmh $50 \mathrm{kw}$ sudah baik dalam sistem kelistrikanya.

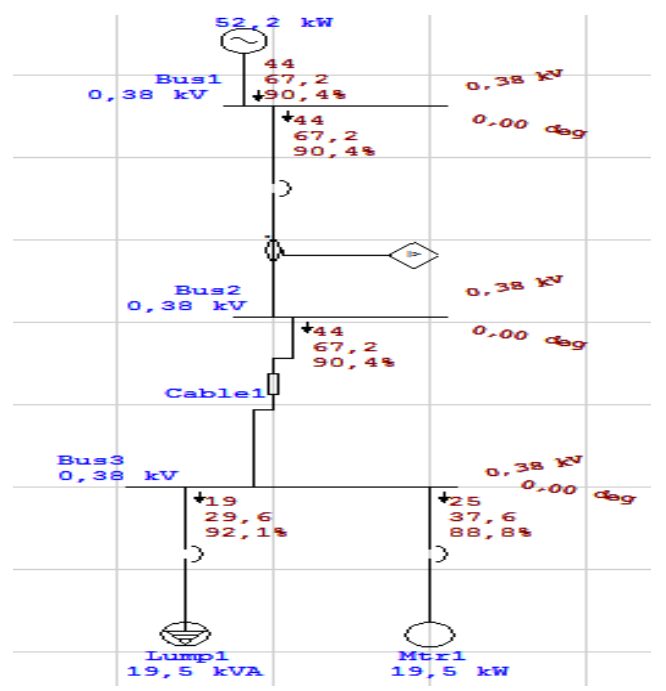

Gambar 3. Simulasi Beban Lump Dan Motor $75 \%$

Pada Gambar 4. dengan kapasitas beban $100 \%$ dapat dilihat generator bertanda merah aliran daya yang di distribusikan oleh generator sudah disetting overload generator tidak trip karena generator yang dipasang secara nyata sebesar $55 \mathrm{~kW}$, sedangkan pada simulasi etap generator disetting dengan berdasarkan daya yang dihasilkan oleh turbin sebesar $52,2 \mathrm{~kW}$. Karena kemampuan turbin berdasarkan efisiensi $82 \%$ adalah 52,2 kW. Pada simulasi aliran daya daiatas tegangan $380 \mathrm{~V}$, daya $59 \mathrm{~kW}$, arus $89 \mathrm{~A}$, dan power faktor 90,7\%. tersampampaikan $100 \%$ kebeban motor $26,1 \mathrm{~kW}$ tegangan $380 \mathrm{~V}$, daya $32 \mathrm{~kW}$, arus 49,4 A, power aktor 89,5\%, beaban lump 26,1 kVA tegangan $380 \mathrm{~V}$, daya $25 \mathrm{kVA}$, arus 39,7 A, power faktor $85 \%$. jadi simulasi etap sistem kelistrikan pltmh $50 \mathrm{kw}$ sudah baik dalam sistem kelistrikanya.

Halaman Web JRRE : http://jurnalnasional.ump.ac.id/index.php/JRRE 


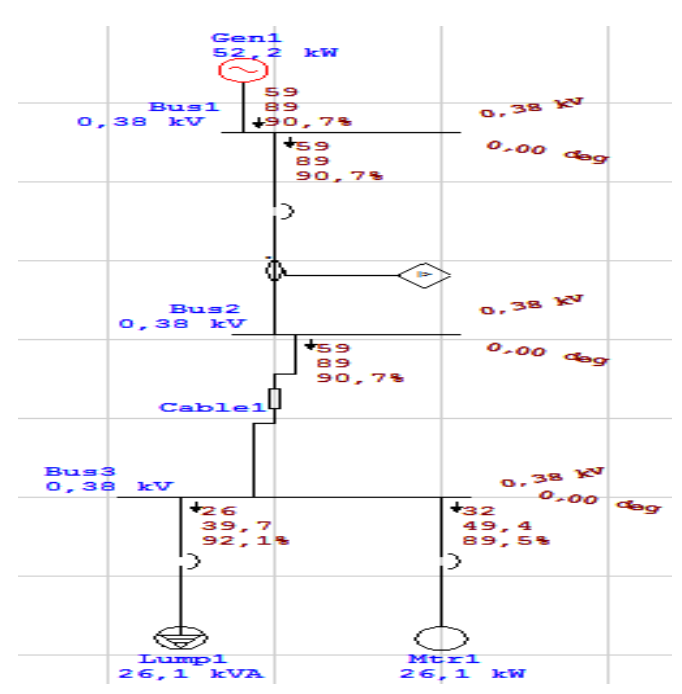

Gambar 4. Simulasi Generator Beban Lump Dan Motor $100 \%$

Untuk perancangan pembangkit listrik mikro hidro (PLTMH) dengan kapasitas daya $50 \mathrm{~kW}$ mebutukan estimasi anggaran biaya produksi sebesar Rp 499,058,000.

Table 5. Estimasi Anggaran Biaya Produksi

\begin{tabular}{|c|c|c|c|c|}
\hline No & Nama komponen & Spesifikasi dan tipe & Qty & Harga \\
\hline & System mekanik & & & \\
\hline 1. & Turbin crossflow & St 37 mild steel & 1 & Rp $350,000,000$ \\
\hline 2. & Generator & Y2-250M-4 55kW(AVR) & 1 & $\operatorname{Rp} \quad 11,305,000$ \\
\hline 3. & Pulley & Ratio $1: 6,5$ & 2 & 400,000 \\
\hline 4. & Panel Box (MDP) & Kotak $60 \times 90 \times 20$ & 2 & $2,000,000$ \\
\hline 5. & Belt & Model Polymax Belt 3M & 2 & 558,000 \\
\hline \multirow[t]{2}{*}{6.} & $\begin{array}{l}\text { System kelistrikan } \\
\text { Proteksi }\end{array}$ & $\begin{array}{l}\text { MCCB tipe } \\
\text { NSX160F160A }\end{array}$ & 1 & 247,000 \\
\hline & & $\begin{array}{l}\text { MCCB EZC100F30115 } \\
115 A\end{array}$ & 2 & $1,558,000$ \\
\hline 7. & Alat Ukur & Voltmeter \& Ammeter & 2 & $1,000,000$ \\
\hline 8. & Kabel Transmisi & Sutrado $300 \mathrm{~mm}^{2}$ AAAC/S & $1 \mathrm{~km}$ & $\operatorname{Rp} \quad 10,750,000$ \\
\hline 9. & Kabel Untuk Beban & Sutrado $12 \mathrm{~mm}$ & $10 \mathrm{~m}$ & 240,000 \\
\hline 10. & Tiang Beton & AAC/NFA2X & 20 & $\operatorname{Rp} \quad 20,000,000$ \\
\hline \multirow[t]{2}{*}{11.} & Jasa & $\begin{array}{l}\text { Tinggi } 13 \text { meter } \\
\text { Orang/hari }\end{array}$ & 20 & $\mathrm{RP} 100,000,000$ \\
\hline & Total biaya & & & Rp 499,058,000 \\
\hline
\end{tabular}

Biaya investasi perancangan pemebangkit listrik mikro hidro (PLTMH) dengan kapasitas daya $50 \mathrm{~kW}$ dengan estimasi anggaran biaya produksi sebesar Rp 499,058,000 meliputi Table 5.

Diasumsikan kapasitas daya PLTMH $50 \mathrm{~kW}$ yang dapat terserap ke beban sebesar $85 \%$ sehingga pendapatan dalam satu tahun adalah :

$85 \% \times 1,457 \times 52,2 \times 8760=\operatorname{Rp} 566,380,508.4$ pertahun.

Halaman Web JRRE : http://jurnalnasional.ump.ac.id/index.php/JRRE 

Table 6.

Biaya pengeliaran pertahun terdiri biaya oprasional perawatan dan gaji operator ditunjukan pada

Table 6 Biaya Oprasional Perawatan Dan Gaji Operator

\begin{tabular}{ll}
\multicolumn{1}{c}{ Uraian } & \multicolumn{1}{c}{ Biaya Pertahun } \\
\hline Biaya Oprasional Perawan & Rp 12,000,000 \\
Gaji Operator 24 jt x 6 karyawan & Rp 288,000,000 \\
Jumlah total & Rp 300,000,000 /tahun
\end{tabular}

Estimasi umur ekonomis pembangkit listrik mikro hidro kapasitas daya $50 \mathrm{~kW}$ sekitar sampai 10 tahun. Maka nilai penyusutan dan residu pembangkitan adalah :

1. Investasi awal = Rp 499,058,000

PPN $10 \%=\operatorname{Rp~49,905,800~}$

Total + PPN $10 \% \quad=$ Rp $548,963,800$

2. Residu $10 \%$

Investasi awal $\quad=\operatorname{Rp~548,963,800~}$

Nilai residu $=10 \% \times \operatorname{Rp} 548,963,800=\operatorname{Rp} 54,896,380$

3. Penyusutan

$$
\begin{aligned}
\text { penyusutan } & =\frac{\text { investasi awal }- \text { nilai residu }}{10} \\
\text { penyusutan } & =\frac{R p 548,963,800-R p 54,896,380}{10} \\
& =\operatorname{Rp} 49,406,742 / \text { tahun }
\end{aligned}
$$

Menurut Kasmir (2003:157) Net Present Value (NPV) atau nilai bersih sekarang merupakan perbandingan antara PV kas bersih dengan PV Investasi selama umur investasi.. Perhitungan diskon factor pada tingkat suku bunga pertahun $10 \%$ :

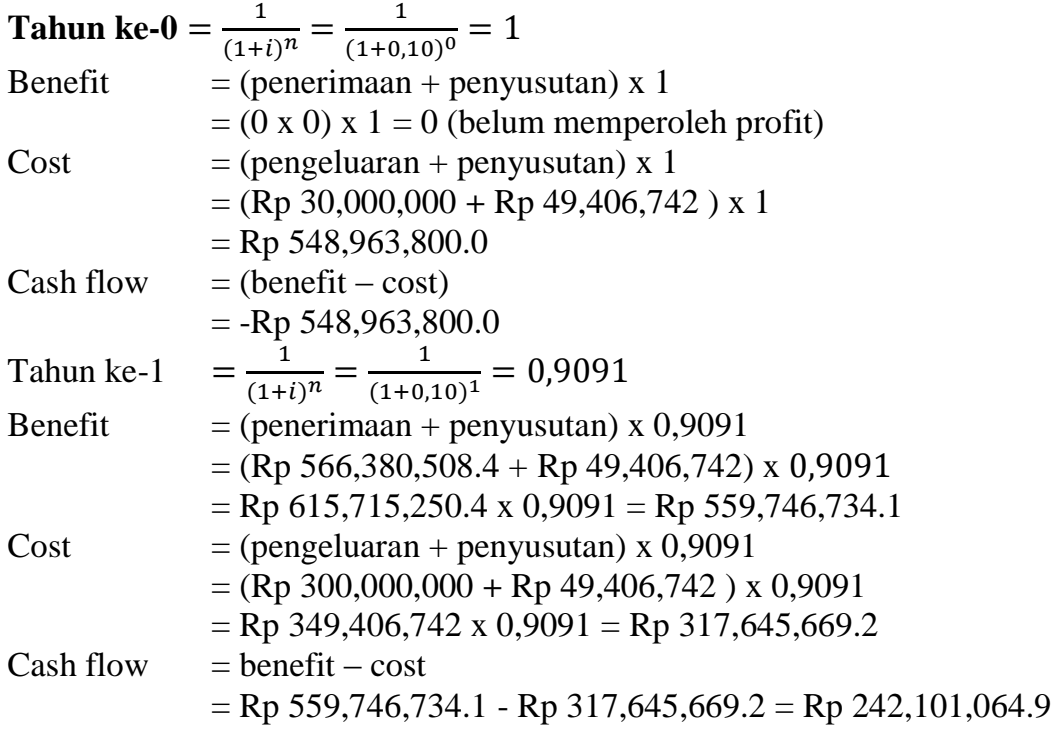

Untuk melihat ke untungan 10 tahun kedepan rincian yang sudah dihitung mengugukan persamaan NPV pada table 7 .

Halaman Web JRRE : http://jurnalnasional.ump.ac.id/index.php/JRRE 
Tabel 7. Present Value

\begin{tabular}{ccccccr}
\hline Tahun & & Benefit & & Cost & & \multicolumn{1}{c}{ Cash Flow } \\
\hline 0 & & & $\mathrm{Rp}$ & $548,963,800.0$ & $-\mathrm{Rp}$ & $548,963,800.0$ \\
1 & $\mathrm{Rp}$ & $559,746,734.14$ & $\mathrm{Rp}$ & $317,645,669.2$ & $\mathrm{Rp}$ & $242,101,065.0$ \\
2 & $\mathrm{Rp}$ & $508,827,082.93$ & $\mathrm{Rp}$ & $288,749,731.6$ & $\mathrm{Rp}$ & $220,077,351.3$ \\
3 & $\mathrm{Rp}$ & $462,586,867.63$ & $\mathrm{Rp}$ & $262,509,285.3$ & $\mathrm{Rp}$ & $200,077,582.4$ \\
4 & $\mathrm{Rp}$ & $420,541,800.70$ & $\mathrm{Rp}$ & $238,649,506.2$ & $\mathrm{Rp}$ & $181,892,294.5$ \\
5 & $\mathrm{Rp}$ & $382,310,727.91$ & $\mathrm{Rp}$ & $216,954,096.5$ & $\mathrm{Rp}$ & $165,356,631.4$ \\
6 & $\mathrm{Rp}$ & $347,555,207.19$ & $\mathrm{Rp}$ & $197,230,996.8$ & $\mathrm{Rp}$ & $150,324,210.3$ \\
7 & $\mathrm{Rp}$ & $315,959,279.26$ & $\mathrm{Rp}$ & $179,300,906.2$ & $\mathrm{Rp}$ & $136,658,373.0$ \\
8 & $\mathrm{Rp}$ & $287,235,708.42$ & $\mathrm{Rp}$ & $163,000,823.8$ & $\mathrm{Rp}$ & $124,234,884.6$ \\
9 & $\mathrm{Rp}$ & $261,123,371.29$ & $\mathrm{Rp}$ & $148,182,567.1$ & $\mathrm{Rp}$ & $112,940,804.2$ \\
10 & $\mathrm{Rp}$ & $237,384,882.99$ & $\mathrm{Rp}$ & $134,711,424.7$ & $\mathrm{Rp}$ & $102,673,458.3$ \\
\hline jumlah & $\mathrm{Rp}$ & $3,783,271,662.45$ & $\mathrm{Rp}$ & $2,146,935,007.4$ & $\mathrm{Rp}$ & $1,636,336,655.0$ \\
\hline
\end{tabular}

Break Even Point ini digunakan untuk mecari sejauh mana investasi awal yang harus diterima untuk mendapatkan titik impas atau kembali modal. Cash out tahun ke- $0=$ investasi awal + residu + Biaya Oprasional Perawatan Dan Gaji Operator

Table 8. Akumulasi Pendapatan Dan Penerimaan

\begin{tabular}{|c|c|c|c|}
\hline Tahun & Cash In /tahun & Cash Out /tahun & Net Cash Flow (laba /tahun) \\
\hline 0 & & $\mathrm{Rp} \quad 548,963,800$ & $548,963,800.0$ \\
\hline 1 & $559,746,734.1$ & $\mathrm{Rp} \quad 903,860,180$ & $344,113,445.9$ \\
\hline 2 & Rp $1,119,493,468.2$ & $\operatorname{Rp} 1,258,756,560$ & $139,263,091.8$ \\
\hline 3 & Rp 1,679,240,202.3 & $\operatorname{Rp} 1,613,652,940$ & $65,587,262.3$ \\
\hline 4 & Rp 2,238,986,936.4 & $\operatorname{Rp} 1,968,549,320$ & $270,437,616.4$ \\
\hline 5 & Rp $2,798,733,670.5$ & $\operatorname{Rp} 2,323,445,700$ & $\mathrm{Rp} \quad 475,287,970.5$ \\
\hline 6 & Rp 3,358,480,404.6 & $\operatorname{Rp} 2,678,342,080$ & $680,138,324.6$ \\
\hline 7 & Rp 3,918,227,138.7 & $\operatorname{Rp} 3,033,238,460$ & $\mathrm{Rp} \quad 884,988,678.7$ \\
\hline 8 & $\operatorname{Rp} 4,477,973,872.8$ & $\operatorname{Rp} 3,388,134,840$ & Rp $1,089,839,032.8$ \\
\hline 9 & $\operatorname{Rp} 5,037,720,606.9$ & $\operatorname{Rp} 3,743,031,220$ & Rp $1,294,689,386.9$ \\
\hline 10 & $\operatorname{Rp} 5,597,467,341.0$ & $\operatorname{Rp} 4,097,927,600$ & Rp $1,499,539,741.0$ \\
\hline
\end{tabular}

Ketetangan :

$$
B E P=X\left(\frac{\text { net cash flow }(\text { laba } / \text { tahun }) \text { sebelum }}{\text { cash flow }(\text { pemasukan } / \text { tahun }) \text { sebelum }}\right)
$$

$\mathrm{x}$ (tahun ke- sebelum balik modal) net cash flow (laba /tahun) sebelum cash flow (pemasukan /tahun) sebelum

$$
\begin{aligned}
B E P & =2\left(\frac{\operatorname{Rp} 139,263,091.8}{\operatorname{Rp} 220,077,351.3}\right) \\
& =2+0,63=2,63=2 \text { tahun }+6 \text { bulan }+3 \text { hari }
\end{aligned}
$$

$$
\begin{aligned}
& =2 \text { tahun } \\
& =\operatorname{Rp} 139,263,091.8 \\
& =\operatorname{Rp} 220,077,351.3
\end{aligned}
$$




\section{KESIMPULAN}

Perancangan distribusi kelistrikan menggunakan simulasi softwere etap untuk melihat aliran daya perancangan PLTMH $50 \mathrm{~kW}$. Pada saat diberi beban lebih dari 100\% atau mendekati $50 \mathrm{~kW}$ tetapi generator akan bekerja baik jika nilai beban kurang lebih $52,2 \mathrm{~kW}$ hal ini dikarenakan turbin akan mngalami penurunan kecepatan saat beban diatas 52,2 kW karena kemampuan turbin berdasarkan efisiensi $82 \%$ adalah $52,2 \mathrm{~kW}$.

Hasil perhitungan NPV pada tingkat suku bunga $10 \%$ untuk masa 10 tahun kedepan mendapatkan sebesar Rp 3,783,271,662.45, berdasarkan kriteria kelayakan yang mengharuskan NPV > 0, Perhitungan dan nilai BEP 2 tahun +6 bulan +3 hari atau dapat mencapai titik impas sebelum umur ekonomis proyek. Berdasarkan hasil evaluasi berarti perancangan pembangkit listrik mikro hidro (PLTMH) kapasitas daya 50 kW ini menguntungkan.

\section{DAFTAR PUSTAKA}

[1] Rizki, Muhammad Kresnawan. 2015. perancangan Pembangkit Listrik Tenaga Mikro Hidro Dengan Tinggi Jatuh Air Kurang Dari 3 Meter. Universitas Islam Indonesia.

[2] Caesar, Febria Awal Ramadhan ayusreza. 2016. Perancangan PLTMH Kapasitas 30 kW Di Desa Giritirta, Kecamatan Pejawaran, Kabupaten Banjarnegara, Provinsi Jawa Tengah, Sekolah Tinggi Teknik PLN

[3] Jumadi dan Faisal Amir. 2017, Perencanaan Dan Perancangan Pembangkit Listriktenaga Mikro-Hidro Jenis Crossflow. Prodi Pendidikan Teknik Mesin Fakultas Keguruan dan Ilmu Pendidikan Universitas Malikussaleh

[4] Ari Maghfur Dimyati oleh perusahan. 2014, Studi Kelayakan Potensi Pembangkit Listrik Tenaga Mikrohidro Di Desa Setren Kecamatan Slogoimokabupaten Wonogiri, Pt.Dinamika Elektrik Mandiri

[5] Alex Okibe Edeoja, Matthew Ekoja and Joshua Sunday Ibrahim Turbine Dimensionless Coefficients and the Net Head/Flow Rate Characteristic for a Simplified PicoHydro Power System. Department of Mechanical Engineering, University of Agriculture, Makurdi, Nigeria

[6] Bryan Patrick Ho-Yan. 2012. Design of a Low Head Pico Hydro Turbine for Rural Electrification in Cameroon. Engineering and International Development Guelph, Ontario, Canada

[7] Anonym. 2008 standarisai peralatan dan komponen pembangkit listrik micro hidro (PLTMH). Jakarta 